\title{
PENGARUH MODERNISASI TERHADAP BAHAN BANGUNAN HUNIAN TRADISIONAL DI DESA ADAT TENGANAN, KABUPATEN KARANGASEM, BALI
}

\author{
I Gede Bagus Rae Indra \\ Program Studi Arsitektur, Fakultas Teknik, Universitas Dwijendra \\ raeindrabagus@gmail.com
}

\begin{abstract}
Abstrak
Desa Adat Tenganan merupakan Desa Bali Aga yang terletak di Kabupaten Karangasem. Sebagai objek wisata desa budaya, Desa Adat Tenganan memiliki keunikan berupa pola tatanan ruang dengan arsitektur bangunan tradisional yang unik, tradisi dan aktivitas adat budaya masyarakat yang khas, serta kerajinan penduduk desa seperti, anyaman ata/bambu, ukiran, dan lukisan diatas daun lontar serta kain tenun gringsing.

Sejalan dengan waktu dan perkembangan yang pesat belakangan ini munculnya kekhawatiran terhadap kelanjutan perkembangan pembangunan di Desa Adat Tenganan, mengakibatkan banyaknya perubahan-perubahan pada bangunan huniannya, terutama pada bahan-bahan bangunan. Kondisi Desa Adat yang sudah mulai meninggalkan bahan untuk bagunan tradisional dan beralih pada bahan bangunan modern. Perubahan tersebut membuat hilangnya tatanan nilai adat masyarakat Tenganan yang menjadi inti dari arsitektur masyarakat setemppat. Sehingga perlu perhatian khusus dan upaya dalam pelestarian tata nilai arsitektur rumah tradisional Tenganan. Sehingga keberadaan rumah adat dan keunikan desa dapat dipertahankan dan tetap memperlihatkan nilai adat rumah tradisional Desa Tenganan, terhadapat bangunan baru yang akan ditempati masyarakat.

Adapun beberapa hal yang mengalami pengaruh modereniasi adalah dari segi bahan bangunan atap, dinding dan bataran. Untuk hal tersebut dibutuhkan upaya bersama pemerintah dan masyarakat setempat untuk melestarikan terhadap perkembangan rumah tinggal tradisional terkait tradisi adat di Desa Adat Tenganan sehingga terwujudnya pembangunan rumah adat yang berkelanjutan.
\end{abstract}

Kata Kunci : Moderenisasi, Rumah Tradisional, Desa Tenganan

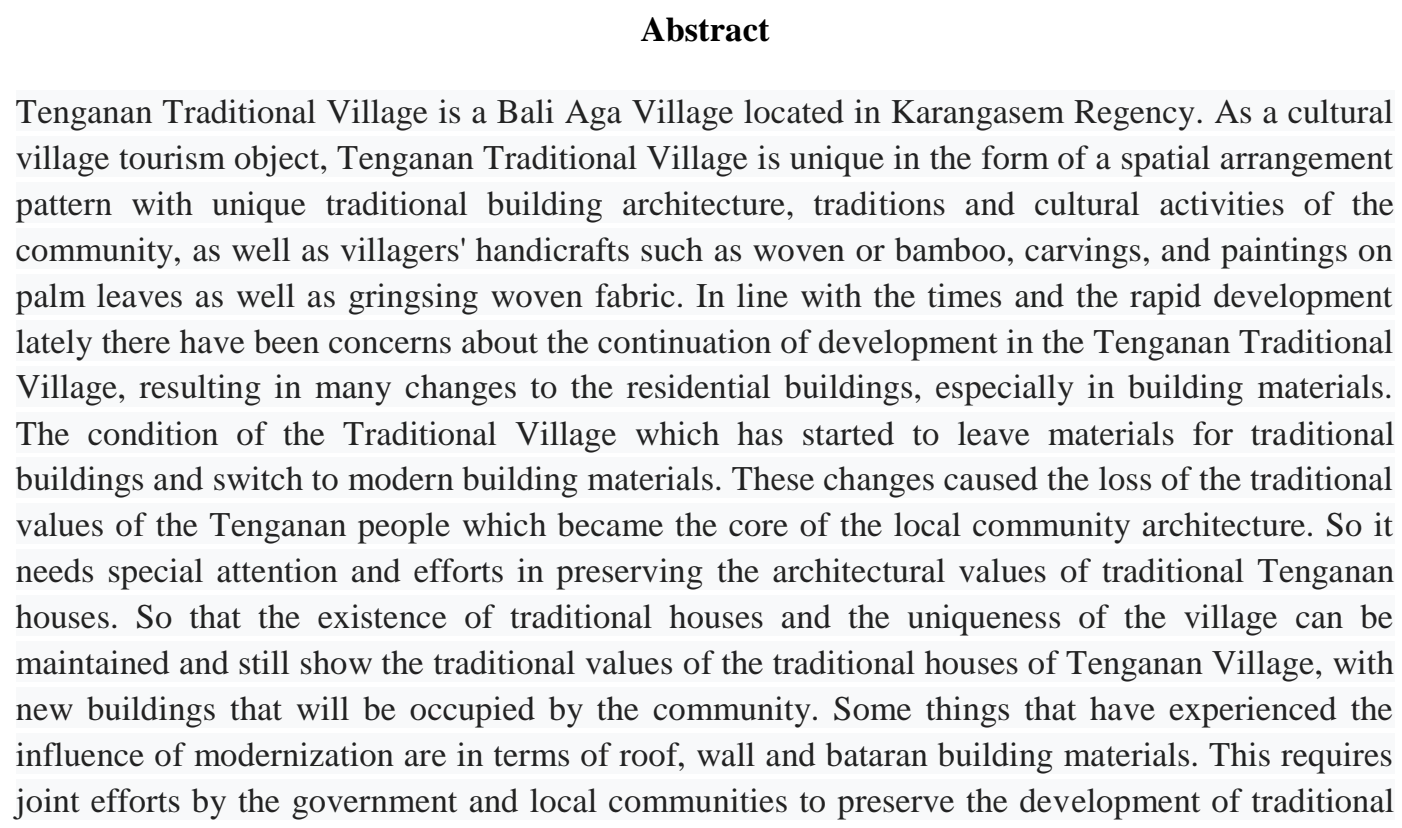


houses related to traditional traditions in the Tenganan Traditional Village so that the construction of traditional houses is sustainable.

Keywords: Modernization, Traditional Houses, Tenganan Village

\section{PENDAHULUAN}

Tenganan adalah salah satu desa tradisional atau desa tua di Bali atau sering disebut Bali Aga. Desa Tenganan adalah desa Bali Aga yang tidak menganut kasta. Desa Tradisional Tenganan memiliki potensi budaya yang sampai saat ini tetap terpelihara dengan baik. Salah satu potensi yang menjadi keunikan yang dimiliki adalah rumah tinggal tradisional.

Rumah tinggal tradisional Desa Adat Tenganan, Kecamatan Manggis, Kabupaten Karangasem merupakan pemukiman yang mempunyai keunikan yang masih mempertahankan adat dan tradisi yang diwariskan nenek moyang yang keberaaannya msih terjaga sampai saat ini.

Tetapi pada saat sekarang ini rumah tradisional Tenganan sudah banyak mengalami perubahan bangunan huniannya, terutama pada material bahan bangunan. Kondisi masyarakat yang sudah mulai meninggalkan material bagunan tradisional dan beralih pada material bangunan modern, membuat hilangnya identitas masyarakat Tenganan pada arsitekturnya. Sehingga kita perlu perhatian khusus dalam melestarikan bagunan rumah tradisional Tenganan untuk tetap dapat memperkenalkan kebudayaan rumah tradisional Tenganan pada arsitekturnya, dan tetap memperlihatkan identitas budaya rumah tradisional Tenganan terhadapat bangunan baru yang akan ditempati masyarakat.

Diperlukan suatu upaya bersama pemerintah dan masyarakat untuk melestarikan rumah tinggal tradisional di Desa Adat Tenganan sehingga terwujudnya pembangunan yang berkelanjutan.

\section{METODE}

Metode Pengumpulan Data

a. Studi Literatur/Referensi, yaitu pengumpulan data yang sifatnya teoritis dari berbagai literatur yang ada kaitannya dengan permasalahan yang di bahas baik dalam bentuk buku, laporan, hasil penelitian statistik, brosur, majalah, dan media cetak lainnya.

b. Observasi/Studi Lapangan, yaitu pengumpulan data dengan cara melakukan pengamatan langsung ke lapangan yakni di Desa Tradisional Tenganan, Karangasem terhadap obyek-obyek atau hal-hal yang berkaitan dengan pembahasan.

c. Wawancara, yaitu melakukan wawancara langsung dengan pihak-pihak yang terkait yang bisa dipercaya keakuratan datanya dan berkaitan dengan bidang yang dibahas untuk mendapatkan informasi yang lebih mendalam tentang obyek pembahasan. Pada penilitian ini wawancara dilakukan dengan warga sekitar Desa Tenganan yakni Bapak Ketut Kawan dan Bapak Nengah Timur.

d. Dokumentasi, yaitu melakukan pengambilan foto-foto atau sketsa untuk dapat memperkuat dan memperjelas maksud dari obyek permasalahan.

Teknik Analisa Data

a. Metode Kompilasi Data, yaitu memilih dan menyusun data yang diperoleh sesuai dengan jenisnya serta data yang disajikan dalam bentuk uraian deskripsi, tabel bagan, sketsa dan foto.

b. Analisa data 
Kualitatif, yaitu data yang tidak berbentuk angka. Hal ini dilakukan dengan cara menganalisis data dengan cara mendeskripsikan data dan membuat diagramatik seperti menyimpulkan beberapa studi banding. Kuantitatif data yang berbentuk angka. Hal ini dilakukan dengan mengunakan pendekatan-pendekatan untuk mendapatkan hasil analisis secara terukur dan pasti dengan membandingkan standar yang ditetapkan dalam teori maupun studi banding. Klasifikasi Data, yaitu pengumpulan data sesuai dengan tingkat kegunaannya, spesifikasinya dalam proses analisa.

\section{HASIL DAN PEMBAHASAN}

Desa Adat Tradisional adalah satu kesatuan wilayah dengan kehidupan sosial budaya masyarakat, memiliki pola tersendiri dilandasi oleh tradisi dan adat setempat. Sehingga rumah tradisional dapat dibedakan mejadi dua tipe yaitu; tipe Bali Aga dan Bali Dataran. Desa Adat Tenganan merupakan salah satu dari bentuk tipe Bali Aga.

Lokasi Desa adat Tenganan bisa dicapai dari kawasan pariwisata Candidasa dengan jarak kira-kira 5km, dan sekitar $18 \mathrm{~km}$ dari Kota Amlapura dan kurang lebih 66km dari Kota Denpasar. Berbatasan dengan desa lainnya, antara lain batas utara Desa Bebandem, batas selatan Desa Pasedahan, barat Desa Ngis dan batas timur Desa Pertima.

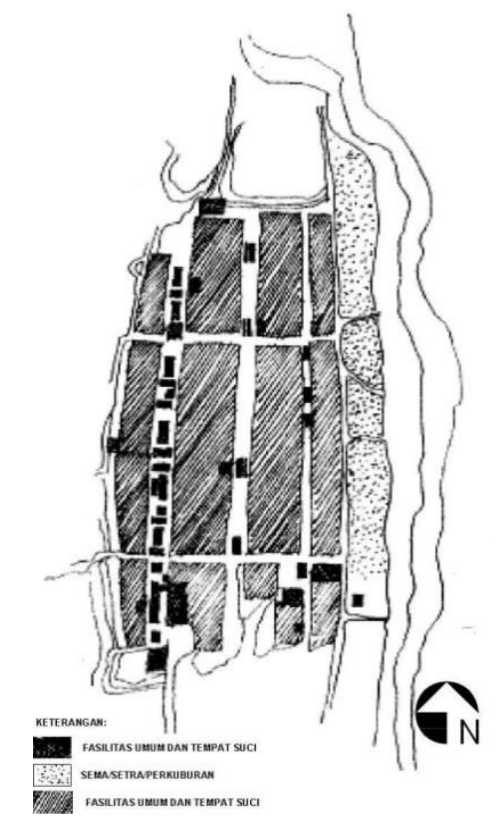

Gambar 1. Pemukiman Desa Adat Tenganan

Desa Adat Tenganan mempunyai luas sekitar $9,53 \mathrm{~km}^{2}$. Mata pencaharian masyarakat Desa Adat Tenganan pada umumnya sebagai petani, sebagian kecil ada sebagai pengerajin anyaman bambu/ata, lukisan dan kain tenun.

\section{Pengaruh Modernisasi terhadap Bahan Bangunan}

Adalah hal yang sepantasnya dilakukan oleh seluruh warga Tenganan untuk menjaga keasrian lingkungan tradisional Desa Tenganan. Namun demikian kini telah banyak bangunan dengan konstruksi modern yang berdiri di dalam areal lingkungan pemukiman tradisional, baik itu karena alasan "renovasi" atau pun kerusakan pada bahan bangunan tradisional yang telah berdiri di pekarangan tersebut sejak lama. Tindakan yang dilakukan warga Tenganan ini bukanlah hal yang salah, namun dengan mengubah bahan bangunan 
yang ada dari tradisional menjadi modern, telah mengurangi nilai kekhasan dan kharisma yang dimiliki oleh Desa Tenganan sebagai salah satu Desa Bali Aga yang dikenal kalangan wisatawan baik domestik maupun mancanegara.

Bahan bangunan yang digunakan pada rumah tinggal tradisional di Desa Adat Tenganan sebelum mengalami pengaruh modernisasi yaitu pada atap menggunakan atap selepan (daun kelapa), pada dinding menggunkan tanah polpolan/tatal sedangkan pada pondasi menggunakan batukali.Tetapi sekarang bahan bangunan tersebut sudah mulai tergatikan oleh bahan bangunan modern.

\section{TINJAUAN RUMAH TRADISIONAL DESA TENGANAN}

\section{Kepala /Atap Bangunan}

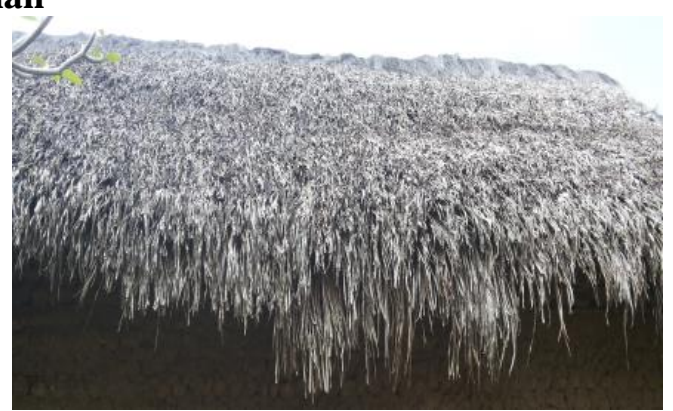

Gambar 2. Daun Kelapa / Selepan

Sumber : dokumentasi pribadi

Atap daun kelapa/selepan adalah atap yang terbuat dari daun kelapa yang dirangkai hingga berbentu sisir, lalu diikatkan pada sebatang bambu yang digunakan sebagai reng. Lapisan daun kelapa minimal 3 lapis, semakin tebal dan rapat lapisannya akan semakin lama daya tahannya.

\section{Badan / Dinding Bangunan}

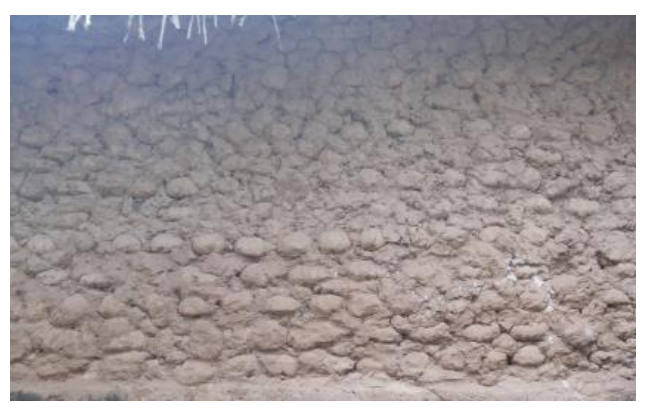

Gambar 3. Tatal / Polpolan

Sumber : dokumentasi pribadi

Tanah polpolan adalah tanah yang diolah dengan cara difermentasikan. Pertama-tama cangkul tanah hingga gembur, ditambahkan air sedikit demi sedikit setelah itu diuleni dengan diinjak-injak sampai kalis lalu diamkan sekitar satu hari. Setelah itu tanah polpolan dibentukkan menjadi bulatan-bulatan sebesar dua kepalan tangan. Ambil sedikit demi sedikit untuk merekatkan pada dinding. Agar berkualitas baik tanah yang digunakan tidak berpasir dan cukup liat dengan warna kecoklatan. 


\section{Kaki / bataran Bangunan}

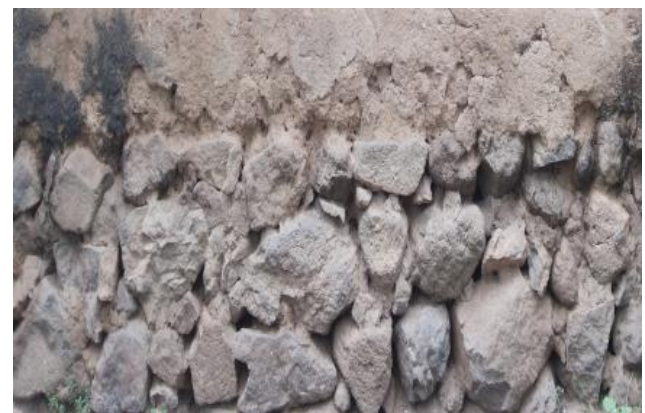

Gambar 4. Batu

Sumber : dokumentasi pribadi

Bataran dibangun dengan batu di kombinasikan dengan tanah merah sebagai perekat.

\section{Faktor Modernisasi}

Ada beberapa faktor yang mempengaruhi terjadinya modernisasi pada bahan bangunan rumah tinggal tradisional di Desa Adat Tenganan adalah :

\section{- Perkembangan Jumlah Penduduk}

Pada saat ini Desa Tenganan mengalami masalah pertambahan jumlah penduduk yang cukup pesat. Hal ini diakibatkan oleh adanya perkembangan ekonomi yang cukup pesat dari aktivitas pariwisata yang dimiliki oleh Desa Tenganan.

Dan selanjutnya penduduk yang terus bertambah membutuhkan ruang untuk tempat tinggal sehingga semakin banyak keluarga yang menghuni setiap pekarangan di Desa Adat Tenganan. Hal ini menyebabkan semakin luasnya area terbangun di masingmasing pekarangan sehingga permukiman desa semakin meluas. Dan lebih memilih menggunakan bahan yang lebih modern dengan alasan bahan mudan dicari.

\section{- Pola Pikir Generasi Muda}

Mengupayakan dan mengembangkan generasi muda yang memiliki kemampuan dan skill adalah salah satu elemen yang penting dalam proses pembangunan masyarakat yang lebih baik di masa depan. Hal ini dapat dengan jelas kita lihat pada proses pendidikan yang dijalani oleh para pemuda pemudi di Bali pada umumnya dan di Desa Tenganan pada khususnya. Hampir seluruh anak muda di Desa Tenganan berpendidikan yang layak. Mereka juga telah mampu memenuhi tuntutan dunia usaha yang kini semakin ketat, baik untuk mencari pekerjaan dan menjalankan pekerjaan itu sebagaimana mestinya. Meski demikian tidak serta merta semua itu bisa memberikan hasil yang baik bagi pengembangan Desa Tenganan ke depan.

Bila kita tengok ke masa lalu, anak-anak remaja terutama di daerah pedesaan cenderung berkutat dengan berbagai usaha yang dijalankan oleh orang tuanya. Anakanak remaja ini nantinya akan cenderung untuk berusaha keras memajukan keluarganya tanpa mengabaikan adat dan budaya yang mereka warisi dari orang tua. Di masa kini, dimana anak-anak remaja telah diserahkan oleh pihak orang tua ke pihak pendidik (sekolah, tempat pembinaan/kursus) tidak hanya dihadapkan dengan pendidikan sesuai dengan kurikulum yang berlaku, namun juga terlibat kontak dengan dunia luar yang sudah mulai berubah akibat arus globalisasi yang demikian keras. Lambat laun, generasi muda ini mulai meninggalkan kebudayaan leluhur mereka dan menggantinya sedikit demi sedikit dengan kebudayaan luar yang mereka peroleh di luar lingkungan desa.

Tak hanya lewat proses pendidikan, aktivitas kunjungan tamu dari luar ke Desa Tenganan pun turut mempengaruhi pola pikir masyarakat termasuk anak-anak remaja yang tinggal di dalamnya. Kunjungan tamu menjadi salah satu hal yang penting bagi 
para penduduk desa demi sedikit tambahan penghasilan untuk memenuhi kebutuhan hidupnya yang semakin meningkat seiring dengan kemajuan jaman.

\section{- Kesehatan}

Pemilihan bahan bangunan perlu diperhatikan terutama untuk kesehatan. Bahan rumah Desa Tenganan di anggap mengganggu kesehatan dan kenyamanan terutama debu dari bahan bangunan, sehingga warga lebih memilih bahan yang lebih modern.

- Material/bahan mudah didapatkan

Warga Desa Tenganan lebih memilih menggunakan bahan modern karena mudah dicari, jenis material yang beragam, yang membuat tampilan bangunan menjadi kokoh dan mewah.

\section{Bahan Atap}

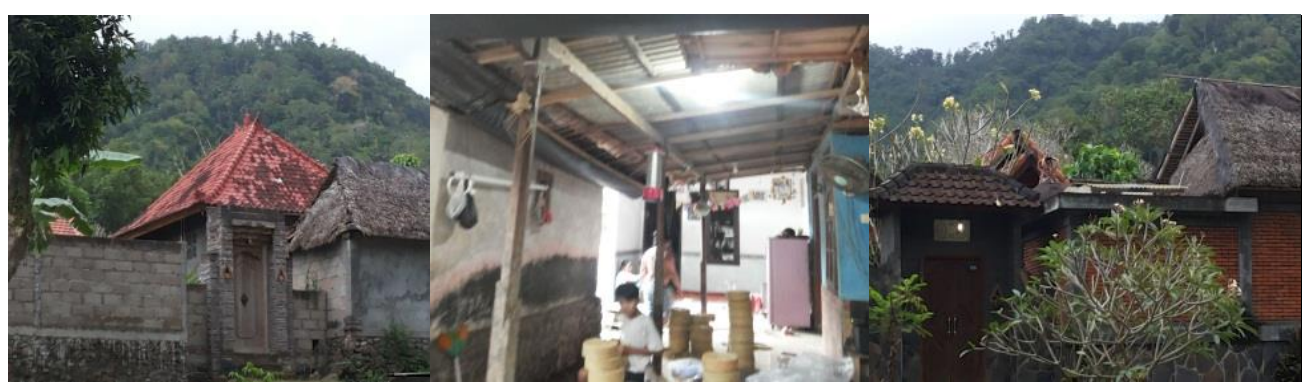

Gambar 5. Bahan Atap

Sumber : dokumentasi pribadi

Bahan atap pada rumah Tradisional Tenganan sudah mulai menggunakan atap genteng, seng, asbes dan juga plat beton. Penggunaan bahan ini lebih tahan lama dan mudah dicari dibandingkan menggunakan selepan atap lebih sering di ganti dan mudah bocor jika hujan.

\section{Bahan Dinding}
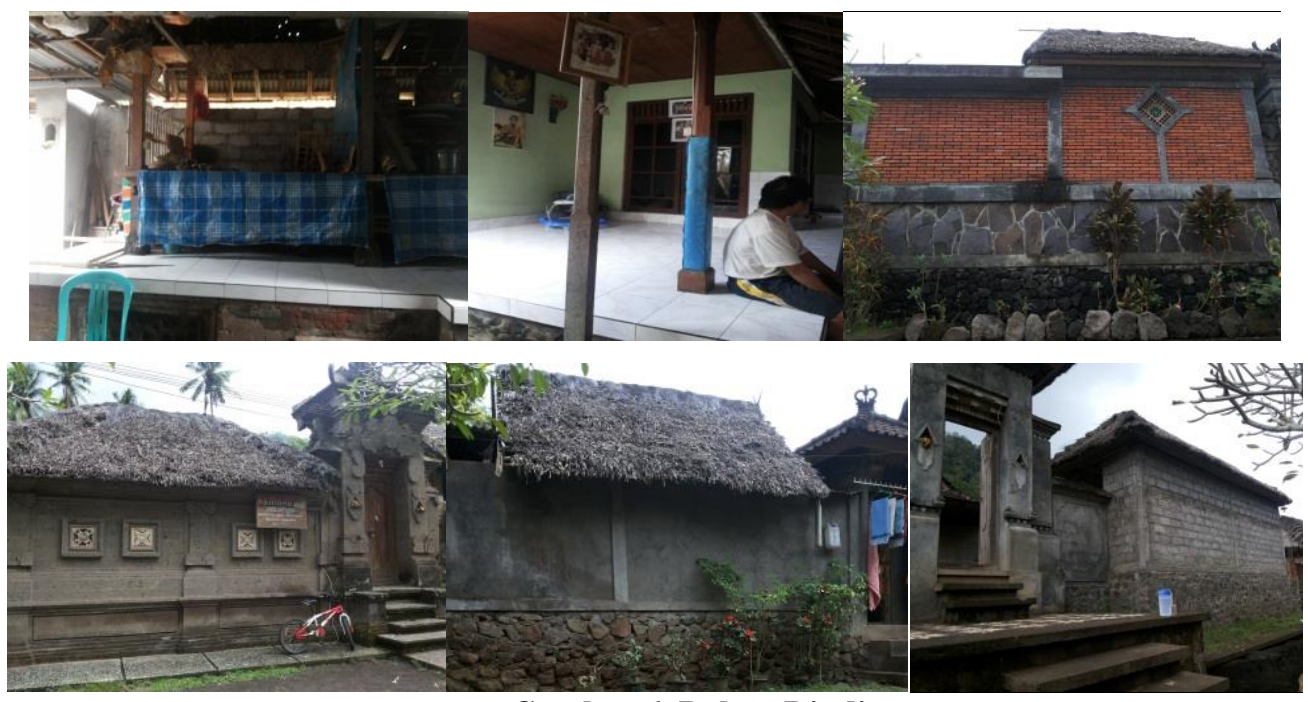

Gambar 6. Bahan Dinding

Sumber : dokumentasi pribadi

Dalam penerapan pada bahan bangunan dinding yang menggunakan bahan bangunan modern yaitu batako, plesteran semen, kaca, batu alam dan bata gosok. Aspek kenyamanan termal dan kekokohan bangunan yang sudah mulai di terapkan pada bangunan. 


\section{Bahan Bataran}

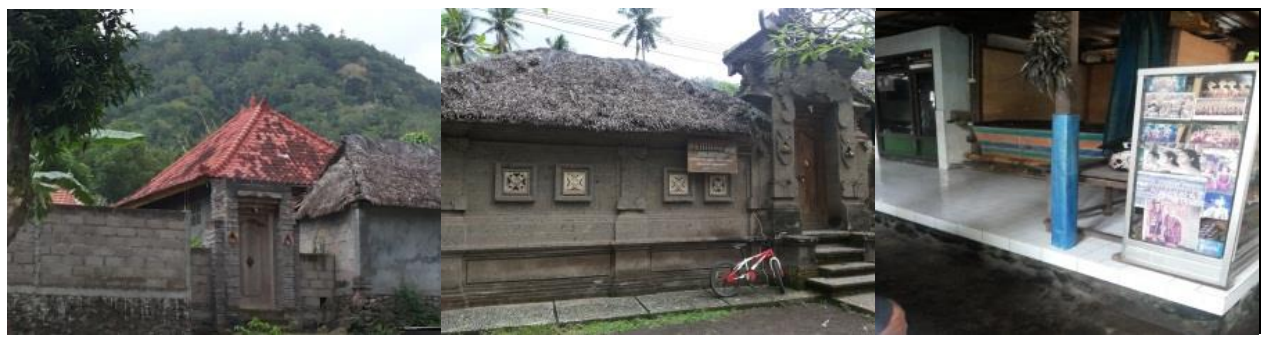

Gambar 7. Bahan Bataran

Sumber : dokumentasi pribadi

Bahan pada bataran bangunan sudah mulai menggunakan bahan modern seperti batako, batu alam dan keramik. Bahan bangunan merupakan semua bahan yang digunakan untuk tujuan konstruksi. Pemilihan bahan bangunan ini berpengaruh besar dalam pembentukan karakteristik bangunan. Bangunan yang baik adalah yang berkarakter, mengakomodir kebutuhan pengghuni, memberikan rasa kenyamanan, keamanan dan kesehatan.

\section{PENUTUP}

\section{Keimpulan}

Bahan bangunan berperan sangat penting dalam mewujudkan bangunan yang kokoh, memiliki fungsi dan estetis atau indah. Bahan bangunan berkembang dari waktu ke waktu seiring dengan berkembangnya kebutuhan manusia akan bangunan itu sendiri guna mewadahi aktifitas-aktifitas manusia yang tidak bisa dilakukan di luar ruangan. Karena aktifitas manusia yang banyak, maka bangunan yang ada juga harus berkarakter. Disinilah bahan bangunan berperan penting. Untuk mewujudkan aktifitas sebagai tempat tinggal, bahan-bahan yang digunakan tentu berbeda dengan wujud banguna untuk aktifitas perkantoran, pertunjukan seni, sarana olahraga dan lain-lain. Penggunaan bahan bangunan juga berperan besar dalam bangunan tersebut.Berkembanganya teknologi dibidang bahan bangunan dan konstruksinya, menyebabkan bangunan lebih tereksploitasi bentuknya, mampu mengadaptasi bentuk-bentuk tertentu yang selama ini sulit diaplikasikan dalam bangunan. Dengan bahan bangunan yang tepat, kita dapat menghadirkan karakter tertentu dalam karya arsitektur kita, bangunan tidak lagi sekedar bentuk fisik biasa, tetapi menjadi aktualisasi diri pemiliknya. Bahan bangunan menjadikan bangunan berkarakter dan hidup.

\section{Saran}

Berdasarkan pada kondisi desa saat ini, permasalahan yang sangat mendesak untuk segera diatasi di Desa Tenganan adalah dampak dari arus modernisasi untuk mencegah situasi yang lebih buruk di kemudian hari. Perlunya kesadaran masyarakat untuk mempertahankan budaya tradisional yang menjadi ciri khas yang dimiliki oleh Desa Adat Tenganan. Untuk mempertahankan hal tersebut perlu adanya aturan yang memiliki sangsi yang tegas bagi masyarakat yang melanggarnya. 


\section{DAFTAR PUSTAKA}

Acwin Dwijendra, Ngakan Ketut. 2003. Perumahan dan Pemukiman Tradisional Bali.

Udiyana, Artha. 2008. Hubungan Sosial Budaya Ekonomi dalam Pembentukan Ruang Pemukiman Tradisional Baliaga

Dinas PU Prop. Dati I Bali, 1989: 6; Parimin Ardi P, 1986: 16; Danker Schaareman, 1986: 2-5)

Anonim, 1986. Kuliah Kerja Bali

https://rumahlia.com/perawatan/atap/jenis-jenis-atap-rumah

https://arsitekturia.com/jenis-bahan-bangunan-untuk-dinding-rumah.html

http://rumahidolaku.com/bahan-bangunan-untuk-dinding-rumah/

https://id.wikipedia.org/wiki/Batu_bata

http://www.mongabay.co.id/2017/08/27/uniknya-aplikasi-tanah-tanpa-semen-dalamarsitektur-bali/

https://www.scribd.com/document/135740115/Pengaruh-Bahan-Bangunan-Terhadap 